\title{
Canadian Agricultural Documents, Federal and Provincial
}

From her vantage point in the reference department at the library of the University of British Columbia, Mrs. Chatwin sends this illuminating description of certain Canadian government publications.

A gricultural documents of Canada, lacking guides of all kinds, are an uncharted sea for librarians. It is impossible to speak as an authority on the subject. With few printed sources to consult, information has had to be built up from three sources:

I. Letters written to the directors or ministers of the various experimental stations and provincial departments of agriculture asking for information regarding specialized fields of research, means of distribution, and indexes or checklists available

2. Study of annual reports and other publications available in the University of British Columbia library

3. Six years' work building up a document collection, with particular attention to agriculture

Necessarily many details are lacking, particularly for the provincial documents.

Since its origin in 1852 the Dominion Department of Agriculture has built up a well-organized department, the hub of which is in Ottawa. Here initial research is done, some of which is later carried to its conclusion at the various experiment stations throughout Canada, where findings can be tested under conditions similar to those experienced by the farmer. The accompanying map shows the location of these stations across Canada. Also situated in Ottawa is the main library of the department, which houses a reference collection of the agricultural publications of all countries, including probably the most complete file on Canadian agriculture in existence. Miss A. L. Shaw, librarian, is most helpful in solving difficulties.

Research in the Department of Agriculture is carried on by four servicesscience, experimental farms, production, and marketing-each with its own allotted field of research. Table I shows the general organization. The work of the four services falls into the following groups:

Science Service- "Solution of practical problems of agriculture through the application of scientific investigations. It deals with problems relating to the ravages of insect pests and diseases affecting plants and animals, the deterioration of plant and animal products through invasion of fungi and bacteria, the nutritional requirements of animals and plants, and the chemistry and microbiology of soils and dairy products." Work in the laboratories is coordinated with research of the National Research Council of Canada and with that of universities and agricultural colleges.

Experimental Farms Service-"Equipped to conduct experiment and research work in connection with practical farm problems in all parts of the Dominion and to demonstrate findings to those in a position to put them into practice."

Production Service-"Gives national leadership in organizing agricultural produc- 


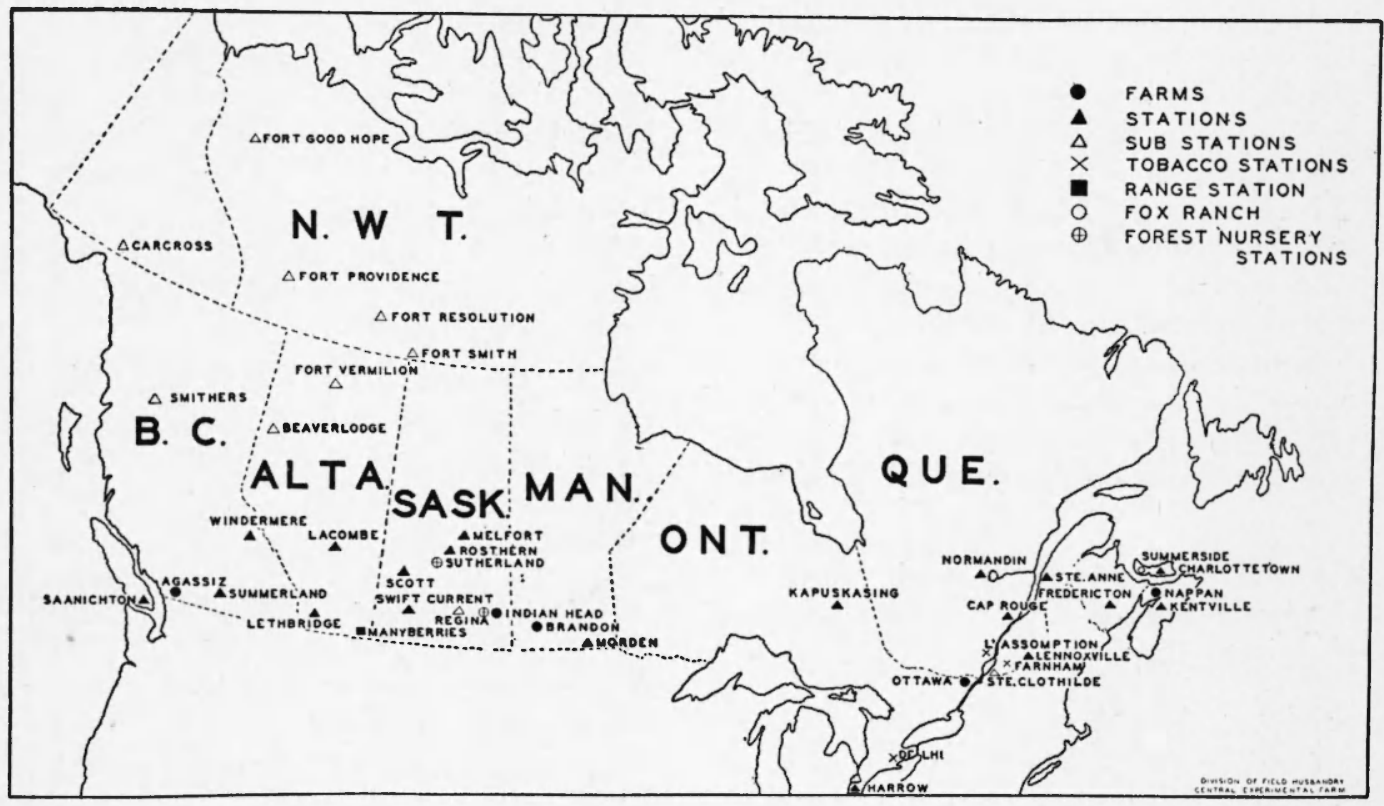

Taken from Fifty Years of Progress on Dominion Experimental Farms 1886-1936, opposite p. 7.

tion. Coordinates work of Dominion and provincial field staffs."

Marketing Service-"Responsible for all activities of the department relating to the efficient marketing of agricultural products under standard grades." 1 Designed to give the lead to planned and profitable production.

Most of the experimental stations carry on general work in field and animal husbandry, forage crops, poultry, and horticulture. Certain specialties have developed however:

Beaverlodge, Alta. Agronomy, northern horticulture, meteorological records, swine husbandry.

Brandon, Man. Breeding of barley, poultry, swine, and dual purpose Shorthorn cattle.

Cap Rouge, Que. 1911-33, breeding of French-Canadian horses and cattle; 1933-,

\footnotetext{
1 The above quotations are from Canada. Department of Agriculture. Directory of Organization and Activities of the Dominion Department of Agriculture, p. 7, 13, 19, 25.
}

horticultural and poultry problems.

Charlottetown, P.E.I. Development of suitable varieties of cereals for the maritimes, poultry, forage crops, fox farming.

Fredericton, N.B. Cattle, swine, fertilizer studies, potatoes.

Harrow, Ont. Tobacco, hybrid corn breeding, soybean breeding, poultry breeding.

Indian Head, Sask. Breeding of Clydesdale horses, Shorthorn cattle, Yorkshire pigs, Barred Rock poultry.

Kapuskasing, Ont. Soil drainage, field, vegetable, and orchard crops.

Kentville, N.S. Horticulture-selecting and growing fruit varieties, handling and marketing the products.

Lacombe, Alta. Swine, poultry, cereal, and forage crops.

L'Assomption, Que. Tobacco (up to 1940); since 1940, horticultural crops, field crops (corn, soybean).

Lennoxville, Que. Cattle, swine, sheep. Pasture improvement, orchard problems.

Lethbridge, Alta. Irrigation and problems of irrigation (the only station on the prairies practising irrigation on a large 
scale), animal breeding, and genetic research.

Manyberries, Alta. Range research, dealing with forage and animal husbandry phases.

Morden, Man. Horticulture, field corn investigations, including plant breeding.

Nappan, N.S. Fertilizer formulae, drainage, and cultural methods on dyke lands. Also to a lesser degree, breeding and feeding of livestock of all kinds.

Scott, Sask. Special work on snow utilization in prairie agriculture, methods of establishing grasses and clovers under semiarid conditions on prairie plains, control of soil drifting, dual purpose Shorthorns.

Summerland, B.C. Horticulture (largely fruits), dairy cattle.

Sutherland Forest Nursery Station, Sask. Research in windbreak trees and fruits (newly established).

Swift Current, Sask. Drought and rehabilitation problems.

Windemere, B.C. Experimental breeding and feeding work-cattle, sheep, and swine.

The most important series currently issued by the Dominion Department of Agriculture are:
Canada. Department of Agriculture.

Annual Report (Experimental farms and stations)

Bulletin (n.s.), I-I8I, 1922-35.

Circular (n.s.), I- I922-

Farm News-Press Clip Sheet

Farmers' Bulletin, I- I935-

Household Bulletin, I- I935-

Pamphlet, no. I-168, 1928-35.

Progress Reports

Report of the Minister, I852-53--

Report of the Proceedings of the Prairie

Farm Rehabilitation Act, 1935-36-

Reports of the branches and divisions

Technical Bulletin, I- I935-

Wartime Production Series, I-

Canada. Department of Agriculture.

Entomological Branch. Annual Report of the Reports I and 2 not published.

Forest Insect Survey, 1938-

Canadian Insect Pest Review, I- April 1923- Monthly.
Each station published an annual report up to 1930. Superseded by the Progress Report.

Series discontinued.

Popular, shorter than the Farmers' Bulletins.

Formerly Press Copy.

Complete studies of agriculture and related subjects, vary in length from four or five to one hundred pages. Nontechnical.

Popular. Subjects of interest to the housewife-canning, baking, menus, buying.

Series discontinued.

Since 1930 the reports of the various experimental farms and stations are issued at irregular intervals of from three to five years and called Progress Reports.

Annual. An administrative report, with a survey of work done or proposed during the year.

Published as separates as well as in the Report of the Minister.

Technical as indicated by title. 
Canada. Department of Agriculture.

Livestock Branch. Canadian Record of Performance for Pure Bred Dairy Cattle, II908-

Canada. Department of Agriculture.

Marketing Service.

Annual Market Review, I- I9I9-

Cold Storage News Letter

Dairy News Letter, I- I9I9-

Dairy Produce Market Report

Economic Annalist, I- Jan. I93I-

Egg and Poultry Market Report

Fruit and Vegetable Weekly Crop and Market Report

Livestock Market Review, I- I920-

Annual.

Monthly.

Monthly.

Weekly.

Monthly.

Weekly.

Weekly.

Weekly.

In 1935 the policy of giving an overall publication number to each document issued was adopted by the Department of Agriculture. The bulletin and pamphlet series were discontinued and the publications divided into four subseries-Farmers' Bulletins, Household Bulletins, Technical Bulletins, and Circulars-with a subseries number as well as the general publication number. The Reports of the Minister and the Wartime Production Series are not included in those given a publication number.

All publications of the department are distributed by the Publicity and Extension Division, Department of Agriculture, Ottawa.

Besides the publications of the Department of Agriculture itself, much valuable statistical material is issued by the Agricultural Branch of the Dominion Bureau of Statistics.

Unfortunately much of the value of this agricultural material is lost because it is unindexed or because librarians have no way of knowing that it exists. Adequate checklists and subject indexes would be a boon to cataloger, reference librarian, and agricultural research worker alike. Until we have them, use of these publi-

cations means wading through hundreds of documents for information, something which few research workers and librarians have the time to do.

Listed below are the checklists and indexes available:

\section{Checklists}

Canada. Department of Agriculture. List of Publications. (Issued annually, formerly as one of the pamphlet series, now as a separate. Arranged by series but giving the publication number and not the series number, which makes it very awkward to use and quite useless for checking any particular series when cataloged as a series and not under the general inclusive publication number. Not cumulative.)

Canada. Department of Agriculture. Outline of Series Issued, I887-1939. Issued by the Main Library, Department of Agriculture, Ottawa, I939. Mimeographed. (Reports, periodicals, separates, and some series are not included.)

Canada. Department of Public Printing and Stationery. Annual Report (Reports up to I939-40 contained a list of annual departmental reports and miscellaneous publications, arranged by title, with no cross references. Since I939-40 this has been omitted.)

Canada. Department of Public Printing and Stationery. Catalogue of Official Publications of the Parliament and Government 


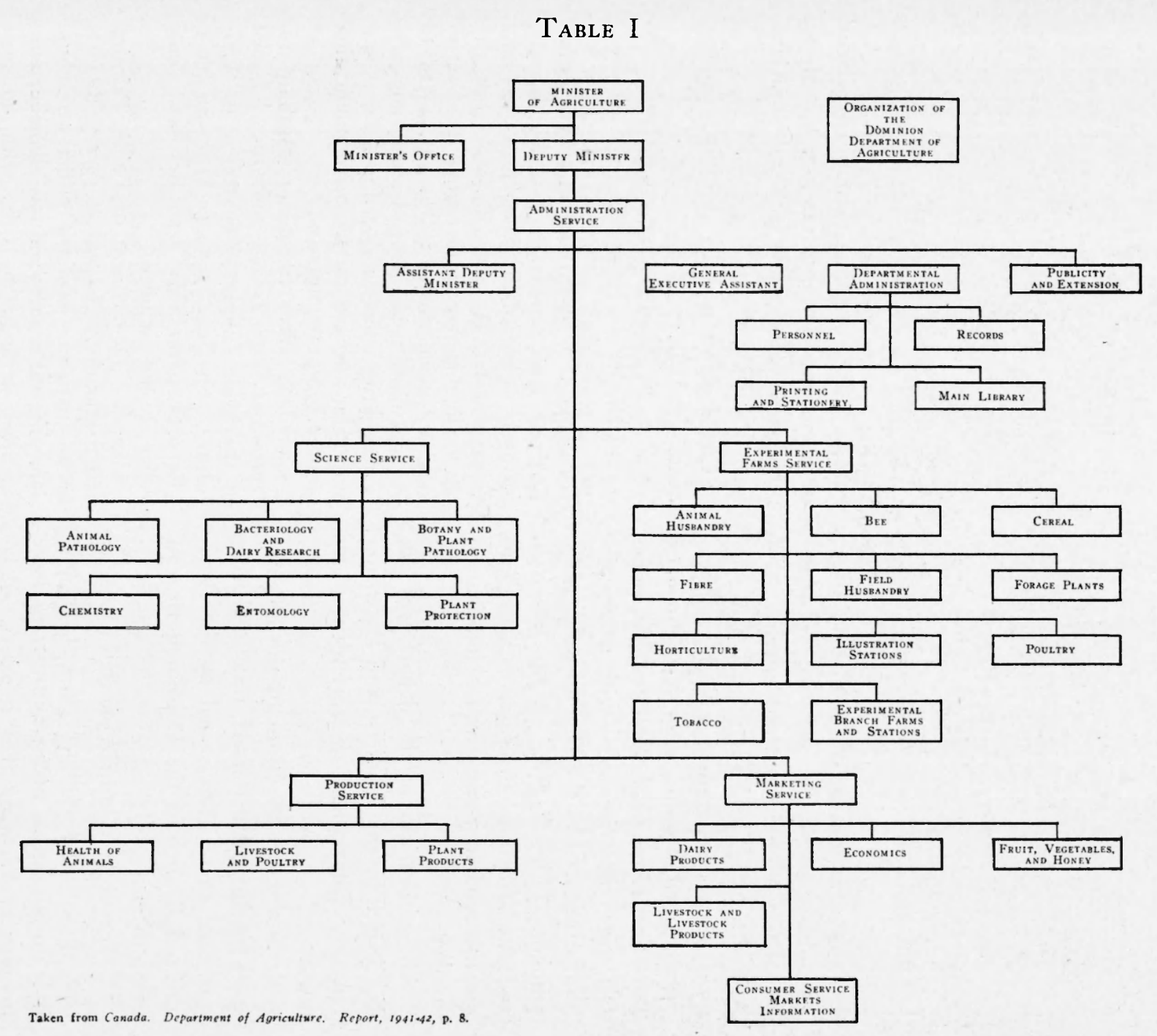


of Canada. (Issued annually up to I938-39, which was the last Catalogue published. A new edition to be issued this fall. Contains titles and selling prices of official publications sold by the King's Printer, which makes it very incomplete as a checklist. Arranged by striking word in the title. $\mathrm{Nu}$ merous cross references.)

Canada. Dominion Bureau of Statistics. Canada Year Book. Ottawa, King's Printer. (Includes a section listing publications of the Dominion departments. Annual reports of the various stations are listed, also reports of the branches; other publications of the Department of Agriculture are omitted.)

Gregory, Winifred, ed. List of the Serial Publications of Foreign Governments, 1815I93I. New York, H. W. Wilson, 1932. (Very out of date but contains the only list of provincial publications in existence, other than the Weston list ${ }^{2}$ for British Columbia and the Library of Congress entries.)

Higgins, Marion V. Canadian Government Publications. Chicago, American Library Association, 1935. (Now hopelessly out of date but still essential for work on Canadian government publications. Since its publication major changes in departmental organization have taken place. Lists Dominion government publications only.)

Ontario Library Review. Public Libraries Branch, Ontario Department of Education, Toronto. (Quarterly. Lists Canadian, British Columbia, Ontario, and Quebec government publications. Very incomplete. The section on British Columbia is a reproduction of the provincial library list of British Columbia documents.)

\section{Indexes}

Agricultural Index. Indexes all the publications series since 1938. Annual Reports are not indexed.

Canada. Department of Agriculture. Index to Publications of the Federal Department of Agriculture of Canada as Follows: Bulletins, I-IOo n.s.; Pamphlets, IIOO n.s.; Circulars, I-70 n.s.; Acts, Orders,

2 Publications of the Government of British Columbia, I87I-I937, a Checklist, by Sydney M. Weston. King's Printer, Victoria, B.C., 1939. and Regulations, I-20. (Pamphlet, no. I22, n.s.) Compiled by the staff of the Main Library. Ottawa, 1930. (An author, subject, and title index for the series indicated. Very brief entry form but useful for the period and series covered.)

Canada. Department of Agriculture. General Index to Reports and Bulletins of the Experimental Farms of the Dominion of Canada, I887-19or. Ottawa, King's Printer, 1902. 194p. (A subject index with good indication of the contents of each publication. Excellent for the period covered.)

Canada. Department of Agriculture. Index to Entomological Publications of the Department of Agriculture, 1884-1936, by A. C. E. Petch. Ottawa, 1938. 410p. Issued in three parts. Mimeographed. (The only index of recent date available. $\mathrm{H}$ as elaborately planned cross references. Arranged alphabetically under scientific names of insects. Contains 4800 names and 15,000 references. Preceding the index proper are abbreviations used for publications reviewed, a list of publications consulted, a bibliography of authors, and a list of authorities with abbreviations. Unfortunately references listed under any particular insect give no indication of the length or title of the articles. A number of inaccuracies in references have been noted in using the index. Despite these weaknesses, it is a useful tool and a decided advance in the right direction.)

Public Affairs Information Service. Indexes the Economic Annalist and the Quarterly Review of Agricultural Statistics (formerly Monthly Review of Agricultural Statistics).

\section{Provincial Agricultural Documents}

The policies of the provincial agriculture departments vary considerably. Some, such as Ontario, Quebec, British Columbia, and Alberta, do considerable research and issue numerous publications. Others, particularly the maritimes, prefer to leave the field of research to the Dominion government and to concentrate on "practical advice to the farmer. 
TABLE II

Provincial Agricultural Publications

\begin{tabular}{|c|c|c|c|c|c|}
\hline & $\begin{array}{c}\text { FIELD(S) OP } \\
\text { SPECIALIZED RESEARCH }\end{array}$ & MAIN SERIES PUBLISHED (CURRENT) & $\begin{array}{l}\text { COMMENTS ON } \\
\text { PUBLICATIONS }\end{array}$ & DISTRIBUTED BY & PUBLICATIONS LISTS AVAIL ABLE \\
\hline Alberta & $\begin{array}{l}\text { General, emphasis on } \\
\text { weed and insect } \\
\text { pests, swine, poul- } \\
\text { try, the home. }\end{array}$ & $\begin{array}{l}\text { Alta. Department of Agriculture. } \\
\text { Annual report Igo5-o6-(earlier reports under } \\
\text { Northwest Territories) } \\
\text { Bullettin } \\
\text { Circular } \\
\text { Joint series (University of Alberta and provin- } \\
\text { cial Department of Agriculture) } \\
\text { Leaflet } \\
\text { Plans (unnumbered) } \\
\text { Separates } \\
\text { Alta. University. College of Agriculture. } \\
\text { Bulletin (technical) } \\
\text { Circular (popular) } \\
\text { Extension circular } \\
\text { Extension leaflet } \\
\text { Mimeographed publications (unnumbered) }\end{array}$ & $\begin{array}{l}\text { Series mainly num- } \\
\text { bered. } \\
\text { General, practical, } \\
\text { largely nontech- } \\
\text { nical. } \\
\text { Fairly uniform in } \\
\text { size. }\end{array}$ & $\begin{array}{l}\text { Agricultural Extension } \\
\text { Service, Department } \\
\text { of Agriculture, Ed- } \\
\text { monton. } \\
\text { Extension Department, } \\
\text { University of Al- } \\
\text { berta, Edmonton. }\end{array}$ & $\begin{array}{l}\text { Mimeographed list of publications of the Alberta Depart- } \\
\text { ment of Agriculture circulars, leaflets, and bulletins all } \\
\text { numbered consecutively in one series. No dates or } \\
\text { authors. Includes only those in print. } \\
\text { Annual report, Publications and Statistics Branch, Agri- } \\
\text { cultural Extension Service. Lists new publications each } \\
\text { year from I } 939 \text { on. } \\
\text { Alta. University. Extension Department. List of Agri- } \\
\text { culliural Prblications Available for Distribution. Ip. } \\
\text { Lists bulletins, circulars, and leaflets in series, giving } \\
\text { numbers, titles, and dates. } \\
\text { Alta. Department of Agriculture. Extension Service. List } \\
\text { of Women's Bulletins and Leafels. Mimeographed. Ip. } \\
\text { Lists bulletins and leaflets of interest to women. No } \\
\text { dates or authors. }\end{array}$ \\
\hline $\begin{array}{l}\text { British } \\
\text { Columbia }\end{array}$ & $\begin{array}{l}\text { Honey, dairy, poultry, } \\
\text { fruit, livestock. }\end{array}$ & 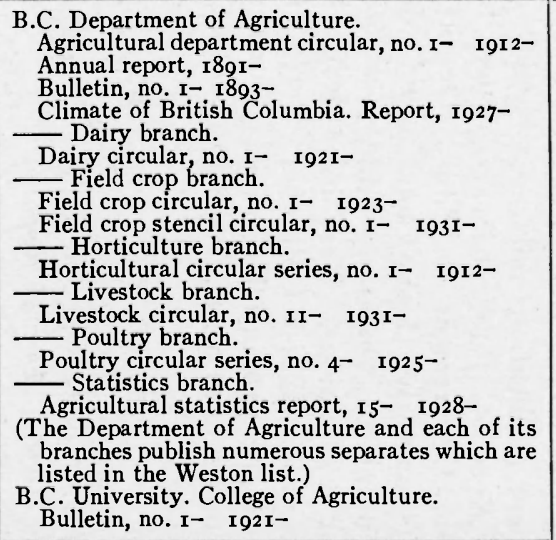 & $\begin{array}{l}\text { Numbered series, } \\
\text { fairly uniform in } \\
\text { size. } \\
\text { Practical, technical, } \\
\text { and nontechnical. }\end{array}$ & $\begin{array}{l}\text { Department of Agri- } \\
\text { culture, Victoria. }\end{array}$ & $\begin{array}{l}\text { Publications of the Government of British Columbia, I871- } \\
\text { ro37, a Checklist, by Sydney M. Weston. King's } \\
\text { Printer, Victoria. I939. \$2. Serials and separates } \\
\text { listed, giving author, title, date, paging, editions, etc., } \\
\text { for each number in a series. } \\
\text { Provincial library list of Recent Government Publications. } \\
\text { Quarterly, cumulated annually. Supplements Weston } \\
\text { list and keeps it up to date. Typewritten. The quar- } \\
\text { terly list is reproduced in the Canadian government } \\
\text { documents section of the Ontario Library Review, the } \\
\text { annual cumulation is not. } \\
\text { Annual report of the Publications Branch, Department } \\
\text { of Agriculture, includes a list of printed publications } \\
\text { for the year. } \\
\text { List of Publications of the Department of Agriculture } \\
\text { Separate, issued annually by the B.C. Department of } \\
\text { Agriculture. Printed. Lists only those publications in } \\
\text { print. Arranged by subjects, in very abbreviated form. }\end{array}$ \\
\hline Manitoba & General. & $\begin{array}{l}\text { Man. Department of Agriculture \& Immigration. } \\
\text { Circular } \\
\text { Crop bulletin } \\
\text { Manitoba Farmers' Library. Extension bulletin. } \\
\text { Separates (some technical) } \\
\text { Man. Soil Survey. } \\
\text { Soils report, no. I- r938- (technical) }\end{array}$ & & $\begin{array}{l}\text { Publications Branch, } \\
\text { Department of Agri- } \\
\text { culture, Winnipeg, or } \\
\text { J L. Johnston, Esq., } \\
\text { Librarian, Provincial } \\
\text { Library, Winnipeg. }\end{array}$ & $\begin{array}{l}\text { List of Publications (Man. Department of Agriculture.) } \\
\text { Ip. Mimeographed. Lists those in print only. Titles } \\
\text { arranged in subject groups. No series, author, date, or } \\
\text { paging indicated. } \\
\text { Manitoba. University. List of Faculty Publications, Ig24- } \\
\text { I937. Contains section on faculty of agriculture pubbl- } \\
\text { cations. Arranged in chronological order of publica- } \\
\text { tions for each author under the various departments. } \\
\text { Very few government publications included. }\end{array}$ \\
\hline
\end{tabular}


TABLE II-Continued

Provincial Agricultural Publications

\begin{tabular}{|c|c|c|c|c|c|}
\hline & $\begin{array}{c}\text { FIELD(s) oF } \\
\text { SPECIALIZED RESEARCH } \\
\end{array}$ & MAIN SERIES PUBLISHED (CURRENT) & $\begin{array}{l}\text { COMMENTS ON } \\
\text { PUBLICATIONS } \\
\end{array}$ & DISTRIBUTED BY & PUBLICATIONS LISTS AVAILABLE \\
\hline New & $\begin{array}{l}\text { Does not enter field of } \\
\text { agricultural re- } \\
\text { search. Feels it is no } \\
\text { use duplicating Do- } \\
\text { minion research. }\end{array}$ & $\begin{array}{l}\text { N.B. Department of Agriculture. } \\
\text { Annual report, 1859-60- } \\
\text { Leaflet, no. I- (Poultry branch) } \\
\text { Separates }\end{array}$ & $\begin{array}{l}\text { Popular, nontechni- } \\
\text { cal. }\end{array}$ & $\begin{array}{l}\text { Department of Agricul- } \\
\text { ture, Fredericton. }\end{array}$ & $\begin{array}{l}\text { List of Publications of the Department of Agriculture. Ip. } \\
\text { Mimeographed. Lists those in print only. No particu- } \\
\text { lar order. No series, author, or date. } \\
\text { Annual report of the Department of Agriculture occa- } \\
\text { sionally mentions a publication or two. }\end{array}$ \\
\hline $\begin{array}{l}\text { Nova } \\
\text { Scotia }\end{array}$ & Soil surveys. & $\begin{array}{l}\text { N.S. Department of Agriculture. } \\
\text { Bulletin, no. I- 1913- } \\
\text { Leaflet, no. I- 1940- } \\
\text { Report, 1886- } \\
\text { Numerous separates. } \\
\text { Bullension division. } \\
\text { Bulletin } \\
\text { Horticulture division. } \\
\text { Bulletin (Horticulture series), no. I- } 1938-\end{array}$ & Practical, popular. & $\begin{array}{l}\text { Department of Agricul- } \\
\text { ture, Halifax. }\end{array}$ & $\begin{array}{l}\text { List of Publications (typed) from Department of Agricul- } \\
\text { ture. 2p. Titles only, arranged in subject groupings. No } \\
\text { series, author, date, or paging. }\end{array}$ \\
\hline Ontario & $\begin{array}{l}\text { Soil research (out- } \\
\text { standing), poultry, } \\
\text { animal nutrition, } \\
\text { vitamin content of } \\
\text { fruits and vege- } \\
\text { tables, storage of } \\
\text { fruits and vege- } \\
\text { tables. } \\
\text { Poultry, dairy, and } \\
\text { disease work carried } \\
\text { on by Bacteriology } \\
\text { and Dairy Depart- } \\
\text { ments of Ontario } \\
\text { College of Agricul- } \\
\text { ture. }\end{array}$ & $\begin{array}{l}\text { Ont. Department of Agriculture. } \\
\text { Annual report, I868- } \\
\text { Bulletin, no. } 3^{-} \text {I886- } \\
\text { Report of the Minister, 1909-10- } \\
\text { Soilsurvey reports } \\
\text { E Statistics and publications branch. } \\
\text { Extension circular, no. I- } \\
\text { Monthly crop report, I- I882- } \\
\text { Monthly dairy report. Bulletin, no. I- I938- } \\
\text { (Separate reports of the various agricultural so- } \\
\text { cieties and branches are also published. These } \\
\text { are also included in the annual report.) }\end{array}$ & $\begin{array}{l}\text { Many technical, } \\
\text { some general in- } \\
\text { terest and popu- } \\
\text { lar. } \\
\text { Bulletins are par- } \\
\text { ticularly useful. } \\
\text { Bulletins 3-46 } \\
\text { were issued as } \\
\text { bulletins of the } \\
\text { Ontario Agricul- } \\
\text { tural College. }\end{array}$ & $\begin{array}{l}\text { Statistics and Publica- } \\
\text { tions Branch, De- } \\
\text { partment of Agricul- } \\
\text { ture, Toronto. }\end{array}$ & $\begin{array}{l}\text { Ontario Library Review includes quarterly list of recent } \\
\text { publications. } \\
\text { List of Agricullural Bulletins and Circulars (Ont. Depart- } \\
\text { ment of Agriculture.) 2p. Mimeographed. Lists those in } \\
\text { print only. Titles arranged in subject groupings, with } \\
\text { bulletin number and date only. } \\
\text { Annual report of the Department of Agriculture. Some } \\
\text { publications listed, very few. } \\
\text { Annual report of Ontario Agricultural College includes } \\
\text { List of Publications. Bulletins printed and mimeo- } \\
\text { graphed and special articles. }\end{array}$ \\
\hline $\begin{array}{l}\text { Prince } \\
\text { Edward } \\
\text { Island }\end{array}$ & $\begin{array}{l}\text { Dairying, poultry, field } \\
\text { crops, fur farming. }\end{array}$ & $\begin{array}{l}\text { P.E.I. Department of Agriculture. } \\
\text { Annual report, } 190 \mathbf{I}^{-}\end{array}$ & & $\begin{array}{l}\text { Department of Agricul- } \\
\text { ture, Charlottetown. }\end{array}$ & None. \\
\hline Quebec & No specialization. & $\begin{array}{l}\text { Quebec. Department of Agriculture. } \\
\text { Bulletin, no. I- I899- } \\
\text { Report of the Minister, 1896-97- } \\
\text { Institute of Oka. } \\
\text { Notes d'economie rurale } \\
\text { La revue d'Oka }\end{array}$ & & $\begin{array}{l}\text { Department of Agricul- } \\
\text { ture, Quebec City. }\end{array}$ & $\begin{array}{l}\text { None, except the Publications of MacDonald College Jour- } \\
\text { nal Series, and the printed list of MacDonald College } \\
\text { study pamphlets. }\end{array}$ \\
\hline $\begin{array}{l}\text { Saskatch- } \\
\text { ewan }\end{array}$ & No specialization. & $\begin{array}{l}\text { Sask. Department of Agriculture. } \\
\text { Annual report, I907- (includes reports of vari- } \\
\text { ous branches) } \\
\text { Annual report of the Commissioner of Co-opera- } \\
\text { tion and Markets, 1913-14- } \\
\text { Bulletin, no. I- I906- } \\
\text { Co-operation and markets news (monthly) } \\
\text { Circular } \\
\text { Crop report, no. I- } \\
\text { Leaflet } \\
\text { Stencils } \\
\text { Standard descriptions }\end{array}$ & $\begin{array}{l}\text { Popular. } \\
\text { Large number of } \\
\text { unnumbered sepa- } \\
\text { rates. }\end{array}$ & $\begin{array}{l}\text { Statistics Branch, De- } \\
\text { partment of Agricul- } \\
\text { ture, Regina. } \\
\text { Extension Department, } \\
\text { University of Sas- } \\
\text { katchewan, Saska- } \\
\text { toon. }\end{array}$ & $\begin{array}{l}\text { Lists of Publications of the Department of Agriculture. } \\
\text { Ip. Mimeographed. Lists those titles in print only, by } \\
\text { series. Frequently no series number given. No author, } \\
\text { date, or paging. }\end{array}$ \\
\hline
\end{tabular}


Table II, showing specialized fields of research, publications issued, distribution agencies, and lists available, was compiled after correspondence with the various provincial departments, consultation of available lists, checking our Library of Congress catalog and files of provincial documents. No claim of completeness is made for the table; it represents merely those series known in this library.

Publications lists of the provinces give only those documents in print; frequently these are titles only and listed in subject groups with no indication as to whether or not they belong in any series. The only really complete checklist is the Weston list for British Columbia. Writing to the departments for information and publications has not been found very satisfactory, and mailing lists are not to be depended on. At present, considering the amount of work necessary to collect these files and the general nature of the publications issued, it is doubtful whether an attempt to build up files of provincial documents is justified. Ontario, British Columbia, and possibly Alberta and Quebec are exceptions to this, as are certain isolated series of a technical nature such as soil reports. Personally I feel it is questionable whether checklists are justified in the case of most of the provinces.

Attention of agriculturalists has recently been given to the problem of federal and provincial documents at a meeting of the Extension Group of the Canadian Society of Technical Agriculturalists. Their Survey Dealing with the Preparation, Publishing, and Distribution of Agricultural Bulletins, 1942, of which a typed copy has been received, reaches certain encouraging conclusions. Attention is given to Dominion-provincial cooperation, mailing lists, and general make-up of bulletins. No mention, however, is made of lack of series numbering or of adequate indexing and listing.

To make Dominion and provincial documents truly usable we need:

I. Checklists and indexes for the cataloger, reference librarian, and research worker

2. Numbering of series, even if only mimeographed

3. Attention to uniformity of size

4. Improved distribution of provincial documents

5. Increased cooperation between federal and provincial departments.

Some specific tools required for effective use of Canadian agricultural documents are:

I. An index of publications of the Canadian Department of Agriculture, modeled on the United States Department of Agriculture Index to Publications

2. A similar index to provincial agriculture publications, either included in the above or issued as a separate

3. A checklist of Canadian government publications (including agriculture) similar to the Document Catalog

4. Checklists of provincial publications similar to the Weston list for Ontario, Quebec, and Alberta

5. A complete revision of Higgins' $\mathrm{Ca}$ nadian Government Publications.

Most of these projects would require a subsidy to cover cost of research and publication. Some, on the other hand, could be done as research projects by librarians doing graduate work-for example, the index to provincial publications could be done in nine sections, one for each province, by a librarian from that province. While such an arrangement would be far from ideal it would at least be a start. Checklists for the various provinces could be done in the same way.

(Continued on page 74) 
took advantage of issuing a reprint for exchange purposes. This time it was $A$ Tennyson Exhibition from the first number of the Colby Library Quarterly.

This year in commemoration of the birth of Henry James we issued for exchange purposes an eight-page pamphlet containing a list of the first editions of Henry James in the Colby library and a genealogical chart showing the various connections of the James family with Colby College.

We have just published a volume of Edwin Arlington Robinson letters to Howard Schmitt, printed by the Southworth-Anthoensen Press of Portland, Me. We were able to issue this volume at a reduction for all prepublication orders.

One of our next experiments will be in the bibliographical field. We hope to have ready for the printer early in 1944 a bibliography of the writings of Rufus $M$. Jones, who is a native of Maine and is "the greatest spiritual philosopher living in America since William James."

In becoming a publisher it is not neces- sary to own a press; the local printer may be able to handle the job. However, unless the local printer is an exceptionally good one, it will pay in the long run to do business with a well-established firm even if you have to go quite a distance to obtain the services desired.

It should be a pleasure and certainly will pay dividends for any library if the librarian sees to it that occasionally some information is prepared regarding treasures which can be passed on to other institutions, scholars, research students, book collectors, etc. This does not mean that the library staff should do the actual work in preparing the material for the press, but they should be responsible for having it done. The library staff knows who of the college faculty are interested and capable of doing the actual editing. Their job is to get these people to do the work. The librarian should be a good judge of whether or not the material is really worthy of passing on to other institutions and know which institutions and individuals are apt to be interested in the material.

\section{Canadian Agricultural Documents}

\section{(Continued from page 70)}

\section{Bibliography}

Alberta. Department of Agriculture. The Department of Agriculture, Its Functions and Services (with Statistical Summary). Edmonton, King's Printer, 1939. (No mention is made in this pamphlet of publications issued by the department.)

Canada. Department of Agriculture. The Department of Agriculture, Its History, Organization, and Work. Compiled and edited by the Publications Branch, Department of Agriculture, 1933. 42p. (The department was completely reorganized in 1939.)

Canada. Department of Agriculture. Directory of Organization and Activities of the Dominion Department of Agriculture. Ottawa, King's Printer, 1939. 32p.

Canada. Department of Agriculture. Fifty Years of Progress on the Dominion Experimental Farms, 1886-1936. Ottawa, King's Printer, 1939. I58p.

Canadian Society of Technical Agriculturists. Extension Group. A Survey Dealing with the Preparation, Publishing, and Distribution of Agricultural Bulletins. 1942. Typew ritten.

(Annual reports of the Department of Agriculture for the Dominion and for each of the provinces were also consulted. Checklists and indexes already listed have not been included in the bibliography.) 